\title{
Preferential adsorption of high density lipoprotein from blood plasma onto biomaterial surfaces
}

\author{
W. Breemhaar, E. Brinkman, D.J. Ellens*, T. Beugeling and A. Bantjes \\ Department of Chemical Technology, Biomaterials Section, Twente University of Technology, PO Box 217, Enschede. \\ The Netherlands \\ * Organon Teknika B.V., Stationsplein 1, Boxtel, The Netherlands \\ (Received 20 September 1983; revised 1 February 1984)
}

\begin{abstract}
In the present study a two step enzyme immuno assay (EIA) was used for the investigation of the adsorption of proteins and lipoproteins from solutions and from blood plasma onto polymer surfaces. It was found that only a small adsorption of the major blood proteins occurred from plasma. Evidence is presented that the reason for this adsorption behaviour is a preferential adsorption of high density lipoprotein (HDL).
\end{abstract}

Keywords: Biomaterial, high density lipoprotein, adsorption, protein

It has generally been assumed that the first event which takes place after contact of blood with a foreign material, is the adsorption of proteins from the blood onto the material surface. An extensive amount of work, including adsorption experiments in which single protein solutions and solutions of protein mixtures were used, has been carried out to obtain more insight into this phenomenon ${ }^{1,2}$.

Protein adsorption may be followed by platelet adhesion and it was reported that this process is dependent on the composition of the adsorbed protein layer. For instance, $\mathrm{Kim}$ et $a l^{3}$ showed that a more pronounced platelet adhesion occurred on surfaces precoated with fibrinogen than on surfaces precoated with albumin. However, Brash and Uniyal ${ }^{4}$ showed that protein adsorption data, obtained from experiments with protein solutions failed to predict the adsorption behaviour of proteins from plasma and that only a restricted adsorption of the major blood proteins occurred.

We recently demonstrated that from human plasma a small adsorption of the blood proteins, albumin, immunoglobulin $G$ and fibrinogen, takes place, presumably due to preferential adsorption of another plasma component ${ }^{5}$. In the present study, in which a two step enzyme immuno assay (EIA) was used, the preferential adsorption of this plasma component was investigated in more detail.

\section{EXPERIMENTAL}

\section{Materials}

Polymers. All experiments described here were carried out with multiwell poly(vinyl chloride) (PVC) microtitre plates (No 1-222-29, Dynatech, Virginia, USA) and polystyrene (PS) microtitre plates (Hepanostika, Organon Teknika, Turnhout, Belgium). PS latex with a particle diameter of $1.10 \mu \mathrm{m}$ was purchased from Serva (FRG).

Proteins. The human proteins, albumin (Alb), immunoglobulin $\mathrm{G}(\mathrm{lgG})$, fibrinogen ( $\mathrm{Fb})$, fibronectin (FN) and citrated human plasma were purchased from the Central Laboratory of the Netherlands Red Cross Blood Transfusion Service (CLB, Amsterdam). Antithrombin III (AT III) was a gift of the American National Red Cross Blood Research Laboratory (Bethesda, Md., USA).

Lipoproteins. The separated fractions of very low density lipoprotein (VLDL), low density lipoprotein (LDL) and high density lipoprotein (HDL) were respectively isolated from human plasma anticoagulated with EDTA ( $3 \mathrm{mmol}$ ) by density gradient ultracentrifugation ${ }^{6}$.

Dilutions were made in $0.02 \mathrm{M}$ phosphate buffered saline $(\mathrm{pH} 7.4)$.

Sera. Rabbit sera directed against Alb, IgG, Fb, AT III, FN and LDL were obtained from CLB, Amsterdam. The rabbit serum directed against $H D L$ was purchased from Behringwerke $A G$ (Marburg. FRG). The anti-HDL and anti$L D L$ are directed against the protein parts of HDL and $L D L$, apoprotein Al (apo-A1) and apoprotein B (apo-B) respectively.

Before use the sera were diluted a 100 times in $0.02 \mathrm{M}$ phosphate buffered saline, containing $1 \%$ bovine serum albumin (PBS-BSA).

Conjugate. Purified sheep anti-rabbit immunoglobin $\mathrm{G}$ (ShalgG) was covalently bound to horse radish peroxidase

(1) 1984 Butterworth \& Co (Publishers) Ltd. 0142-9612/84/050269-06\$03.00 
(Boehringer Mannheim, FRG) by a modified thiolation method according to Carlsson, Drevin and Axen ${ }^{7}$.

Before use the conjugate was diluted $1: 2000$ in $0.02 \mathrm{M}$ Tris buffer (pH 7.4), containing $0.02 \mathrm{M} \mathrm{NaCl}, 1 \%$ BSA, $1 \%$ polyethylene glycol 6000 an $125 \mathrm{mg}^{-1}{ }^{-1}$ ShalgG. Urea peroxide (Hepanostika, Organon Teknika) was used as the enzyme substrate and 3,3', 5,5' - tetramethylbenzidine (Fluka, Switzerland) as the leukodye ${ }^{8}$.

\section{Methods}

Protein adsorption studies. The wells of the PVC and PS microtitre plates were contacted with $0.075 \mathrm{ml}$ of a protein or plasma solution obtained by serial dilution at $20^{\circ} \mathrm{C}$ for $1 \mathrm{~h}$. During the protein adsorption evaporation of the solution from the wells was prevented by covering the plates.

After the contact time the wells of the plates were emptied and washed 4 times with $0.15 \mathrm{ml} 0.01 \mathrm{M}$ phosphate buffered saline $(\mathrm{pH} 7.4)$ containing $0.05 \%$ Tween$20^{R}$ (PBS-Tw), using a multichannel syringe. During each washing procedure the wells were contacted for $30 \mathrm{~s}$ with PBS-Tw.

Detection of adsorbed proteins. Solutions $(0.05 \mathrm{ml})$ of the first antibody (serum) were applied to each of the washed wells of one series. To the wells of another series $0.05 \mathrm{ml}$ PBS-BSA was added to obtain negative controls. After $1 \mathrm{~h}$ of incubation at $20^{\circ} \mathrm{C}$ the wells were washed 4 times with $0.15 \mathrm{ml}$ PBS-Tw. Then $0.05 \mathrm{ml}$ of the conjugate solution was added to each of the wells and incubated for $1 \mathrm{~h}$ at $20^{\circ} \mathrm{C}$. After washing 4 times with $0.15 \mathrm{ml}$ PBS-Tw, $0.1 \mathrm{ml}$ buffer solution containing the enzyme substrate and leukodye ${ }^{8}$ was added to each of the wells and incubated in the dark for $30 \mathrm{~min}$. at $20^{\circ} \mathrm{C}$. The enzyme induced colour reaction was then stopped by adding $0.025 \mathrm{ml} 2 \mathrm{M} \mathrm{H}_{2} \mathrm{SO}_{4}$ to the substrate solution in the wells of the microtitre plate and finally the absorbance at $450 \mathrm{~nm}\left(\mathrm{~A}_{450}\right)$ was determined by using a colourimeter provided with a $80 \mu \mathrm{l}$ flow through cell (Vitatron).

The points as shown in the figures represent average absorbance values. Each of these values is the result of at least six experiments. The error bars represent the S.D.

Semi-quantitative determination of the amount of adsorbed albumin on PS microtitre plates. PS latex depletion experiments ${ }^{9}$ were carried out in the following way. Alb solutions $(0.543 \mathrm{ml})$ of various concentrations were added to $0.457 \mathrm{ml}$ of PS latex suspensions. The surface area of PS latex varied from $200-2500 \mathrm{~cm}^{2}$. After an incubation time of $1 \mathrm{~h}$ at $20^{\circ} \mathrm{C}$ the suspensions were centrifuged for $30 \mathrm{~min}$. at $12000 \mathrm{rpm}$. For both the original Alb solution and the clear supernatant the Alb concentration was determined by measuring the absorbances at $280 \mathrm{~nm}$. The amounts of adsorbed Alb were compared with the absorbance $(450 \mathrm{~nm})$ of the generated dye in the corresponding enzyme immuno assays.

\section{RESULTS AND DISCUSSION}

Adsorption isotherms of $\mathrm{Alb}, \mathrm{IgG}$ and $\mathrm{Fb}$ which were determined for the adsorption on the materlals polylvinyl chloride) (PVC) and polystyrene (PS) are shown in Figures $1(a)$ and $1(b)$. These isotherms were obtained from serial dilution experiments in which the solutions contained one single protein.
The amount of protein adsorbed from the solution on the polymer surface is expressed as the absorbance $\left(A_{450}\right)$ of the dye which is generated in the two-step enzyme immuno assay. A quantitative relationship between the absorbance and the amount of protein(s) adsorbed has not yet been determined. Preliminary investigations in which results from the two-step enzyme immuno assay were compared with those obtained from PS latex depletion experiments indicate that an absorbance of $1.0(450 \mathrm{~nm})$ corresponds to about $0.07 \mu \mathrm{g}$ adsorbed Alb. $\mathrm{cm}^{-2}$. The values obtained from our depletion experiments are in agreement with those reported by Norde et al. ${ }^{9}$. A more extensive study is
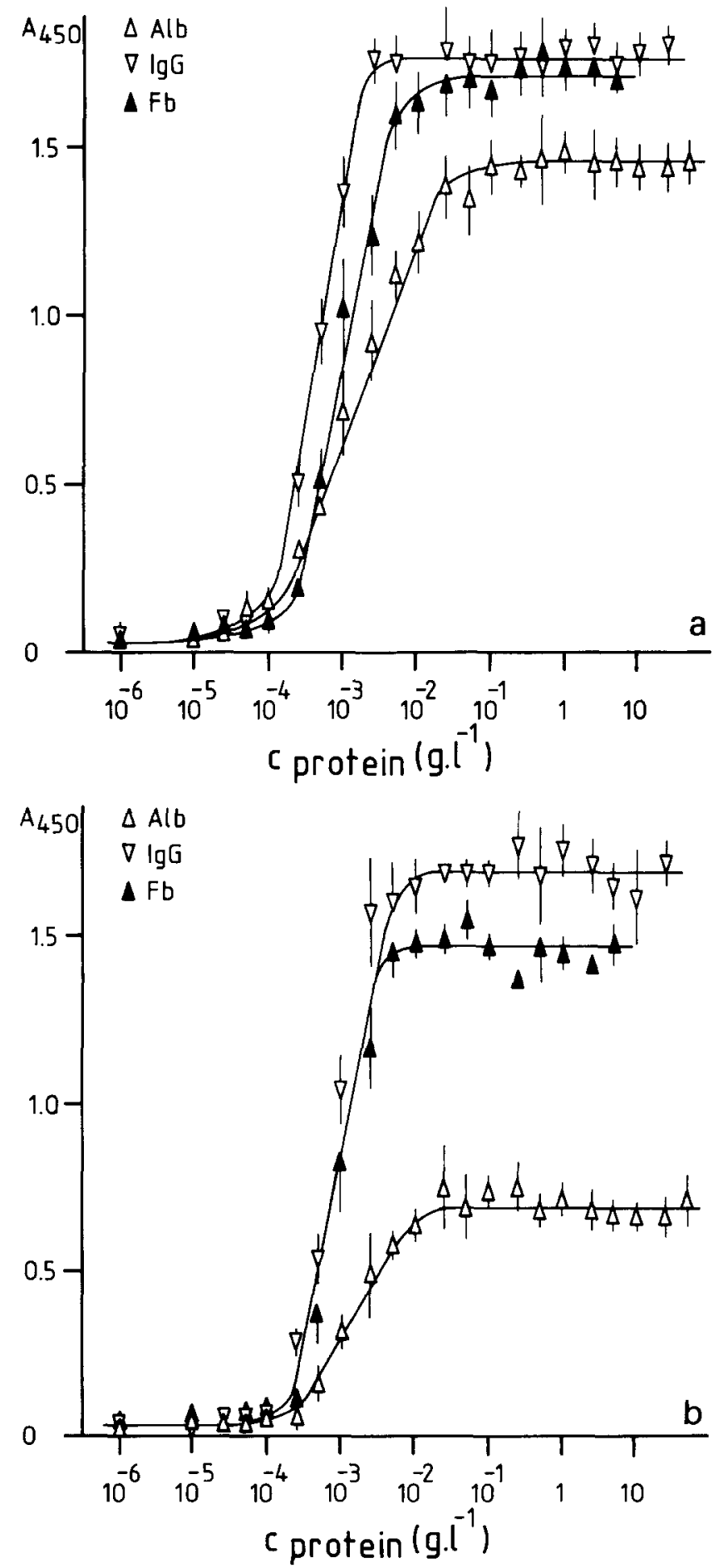

Figure 1 Adsorption isotherms for the adsorption of $A / b, \lg G$ and $F b$ obtained by serial dilution of single protein solutions. (a) on PVC; (b) on PS. 
necessary in order to establish a precise relationship between the absorbance of the generated dye and the amount of protein adsorbed and to see whether or not the same relationship is found for different proteins.

The adsorption isotherms of the above mentioned proteins reach a plateau value at relatively low protein concentration; a further increase of protein concentration does not result in a further increase of the absorbance of the dye.

Adsorption measurements of $\mathrm{Alb}, \mathrm{lgG}$ and $\mathrm{Fb}$ from protein mixtures (Alb: $\operatorname{lgG}: \mathrm{Fb}=10: 5: 1, \mathrm{w} / \mathrm{w}$ ) are represented in Figures $2(a)$ and $2(b)$. The ratio $(w / w)$ of the three proteins present in the mixtures is about the same
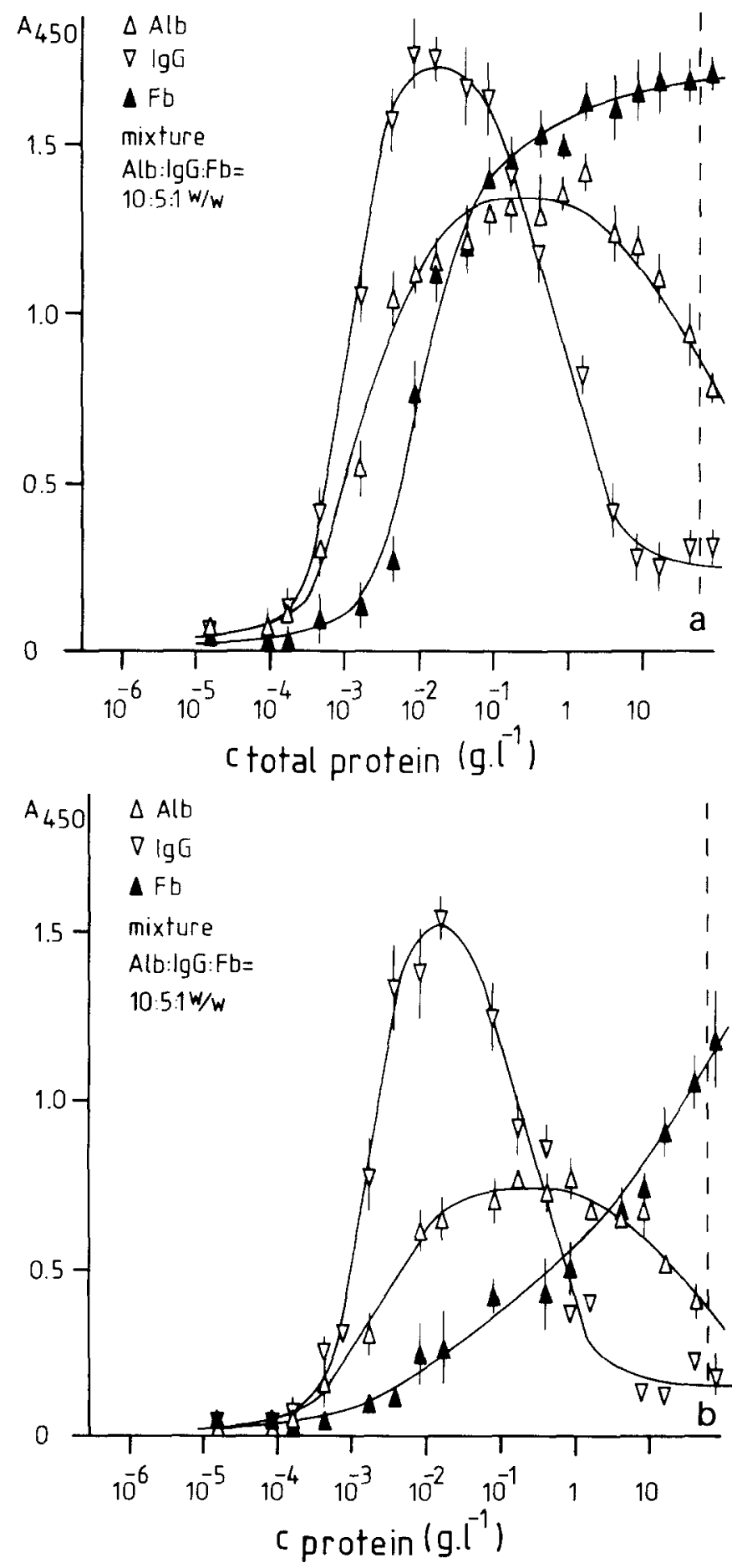

Figure 2 Adsorption isotherms for the adsorption of $A / b, \lg G$ and $F b$ obtained by serial dilution of protein mixtures. The position of the dotted line corresponds with the physiological concentration of the three proteins in the p/asma. (a) on PVC; (b) on PS. as found in human plasma. The amounts of Alb and IgG adsorbed on PVC (Figure 2a) reach a maxima at protein concentrations of approximately $10^{-2}$ and $10^{-1} \mathrm{~g} \cdot \mathrm{I}^{-1}$ respectively and from there decrease. $\mathrm{Fb}$ reaches a plateau level as found for the adsorption of this protein from single protein solutions. Evidently, a preferential adsorption of $\mathrm{Fb}$ from concentrated solutions of the mixed proteins $\mathrm{Fb}, \mathrm{Alb}$ and IgG takes place. A preferential adsorption of $\mathrm{Fb}$ was also found when PS microtitre plates were used (Figure $2 b$ ). These results are in agreement with those of Kim and Lee ${ }^{10}$ who also observed a preferential adsorption of $\mathrm{Fb}$ from mixtures of $\mathrm{Alb}, \mathrm{IgG}$ and $\mathrm{Fb}$ on several material surfaces.

When PVC was exposed to undiluted plasma none or only a very small adsorption of $\mathrm{Alb}, \mathrm{IgG}$ and $\mathrm{Fb}$ took place (Figure 3a). Similar results were obtained when PS was used instead of PVC (Figure $3 b$ ). The amount of adsorbed $\mathrm{Fb}$, especially, is small compared with the amount of $\mathrm{Fb}$ adsorbed from a solution in which the concentrations of $\mathrm{Alb}, \operatorname{lgG}$ and $\mathrm{Fb}$ are equal to those in plasma. The results mentioned above are in agreement with those of Brash and Uniyal ${ }^{4}$, who showed that protein adsorption data from experiments in which protein solutions were used, failed to predict protein adsorption data from plasma and that only a small adsorption of the major blood proteins occurred.

The low adsorption of protein(s) from plasma onto polymer surfaces presumably has to be attributed to the preferential adsorption of another plasma component, probably a component which is present in a relatively high concentration. Therefore adsorption experiments were carried out in which, the adsorption of FN, AT III and lipoproteins from solutions and from plasma were studied. Moreover, the effect of the presence of these components on the $\mathrm{Fb}$ adsorption was investigated.

The adsorption isotherms of HDL and LDL, obtained from adsorption experiments on PVC with single lipoprotein solutions are given in Figure 4. The amounts of these lipoproteins are expressed as the concentrations of the apoproteins apo-A I and apo-B respectively.

Adsorption isotherms of these lipoproteins from plasma (Figure 5) are different compared with those mentioned above. LDL (apo-B) shows an overall low adsorption level; a maximum could not be detected. At increasing plasma concentration the HDL adsorption on PVC increases and reaches a plateau value of about $80 \%$ of the one obtained for the experiments in which solutions of the single lipoprotein were used (Figures 4 and 5). Evidently, the adsorption of HDL is not much influcnced by the presence of large amount sof proteins in plasma. As is also shown in Figure 5 the amount of $\mathrm{Fb}$ on the PVC surface reaches a maximum at low plasma concentration and thereafter decreases.

The adsorption isotherms of $\mathrm{Fb}$ obtained by seria dilution of a mixture of $\mathrm{Fb}$ and VLDL show that the adsorption of $\mathrm{Fb}$ is not influenced by the presence of VLDL (Figures 6 and 1 a). When similar experiments were carried out in which mixtures of Fb and HDL (Fb: HDL = $3.3: 1, w / w)$ or $\mathrm{Fb}$ and $\mathrm{LDL}(\mathrm{Fb}: \mathrm{LDL}=4.2: 1, \mathrm{w} / \mathrm{w})$ were used, the adsorption of $\mathrm{Fh}$ from concentrated solutions was found to be less compared with the adsorption from the pure Fb solutions (Figure 6). However, this decrease in $\mathrm{Fb}$ adsorption is much more pronounced when $\mathrm{HDL}$ is present in the mixture. This adsorption behaviour of $\mathrm{Fb}$ corresponds well to the one found from experiments in which plasma was used (Figure 4). 

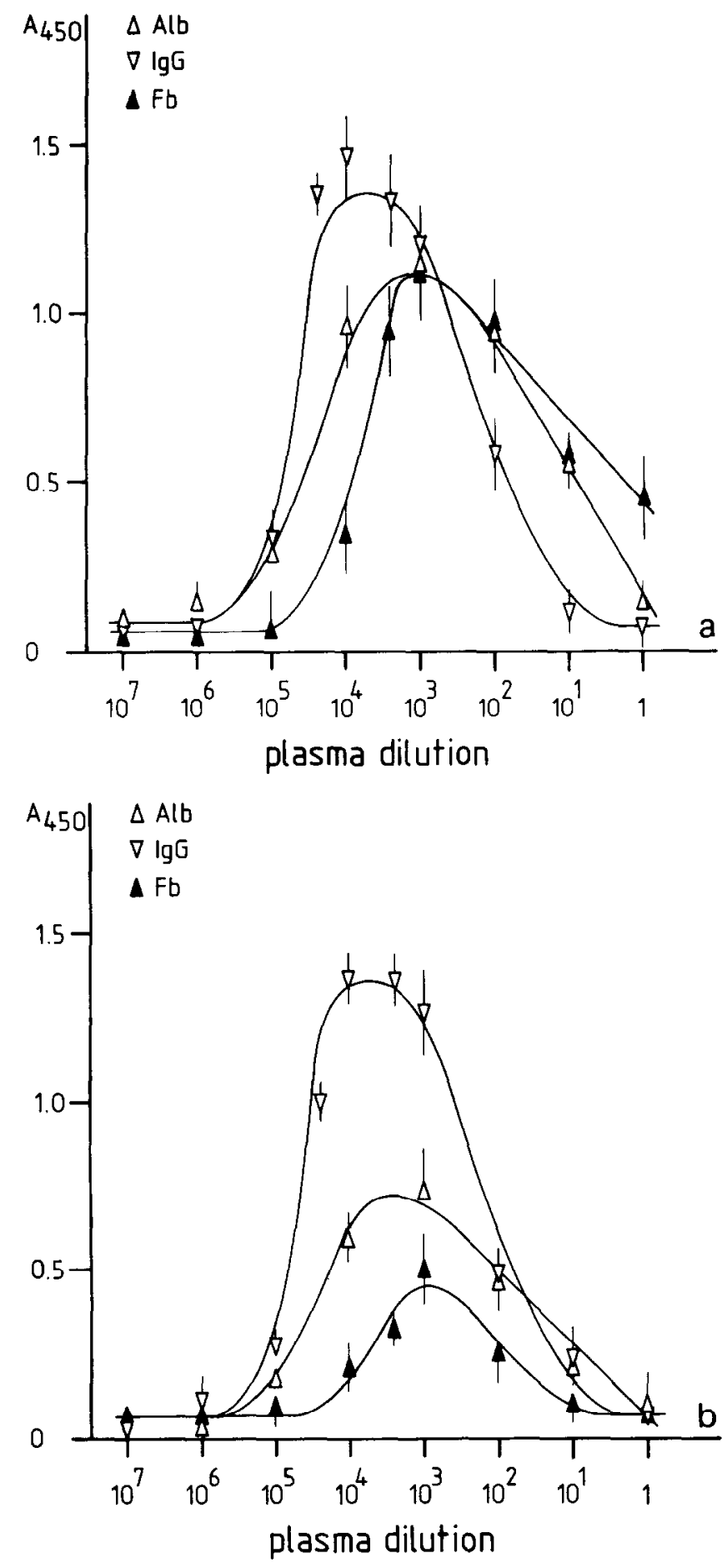

Figure 3 Adsorption isotherms for the adsorption of $A / b, I g G$ and $F b$ obtained by serial dilution of citrated plasma. (a) on PVC; (b) on PS.

The effect of the presence of HDL on the adsorption of $\mathrm{Fb}$ onto polymer surfaces is also shown in Figure 7. In the experiments concerned solutions with a fixed concentration of $\mathrm{Fb}\left(2.5 \mathrm{~g} \cdot \mathrm{I}^{-1}\right)$ and an increasing concentration of $\mathrm{HDL}$ were contacted with PS. At low HDL concentrations $\left(<10^{-5} \mathrm{~g} \cdot \mathrm{I}^{-1}\right)$ the adsorption of $\mathrm{Fb}$ on PS is about the same as found from pure Fb solution, but at relatively high concentrations of $\mathrm{HDL}$ the adsorption of $\mathrm{Fb}$ is severely reduced.

As reported previously ${ }^{5}$ competition experiments as described above were also carried out with solutions of Alb which contained a fixed concentration $\left(0.2 \mathrm{~g} \cdot \mathrm{I}^{-1}\right)$ FN or AT III and with solutions of $F b$ which contained a fixed concentration of Alb $\left(25 \mathrm{~g} \cdot \Gamma^{-1}\right)$. The adsorption behaviour of Alb was not found to be influenced by the presence of FN or AT III. Moreover, it was found that minimal amounts of FN and AT III adsorbed from plasma (and mixed protein solutions) onto polymer surfaces. Also the adsorption behaviour of $\mathrm{Fb}$ was not influenced by the presence of Alb when the protein concentrations were about the same as found in plasma.

Figure 8 shows the result of experiments in which the $\mathrm{Fb}$ adsorption from solutions of $\mathrm{Fb}$ was measured after PS surfaces were precoated with solutions containing

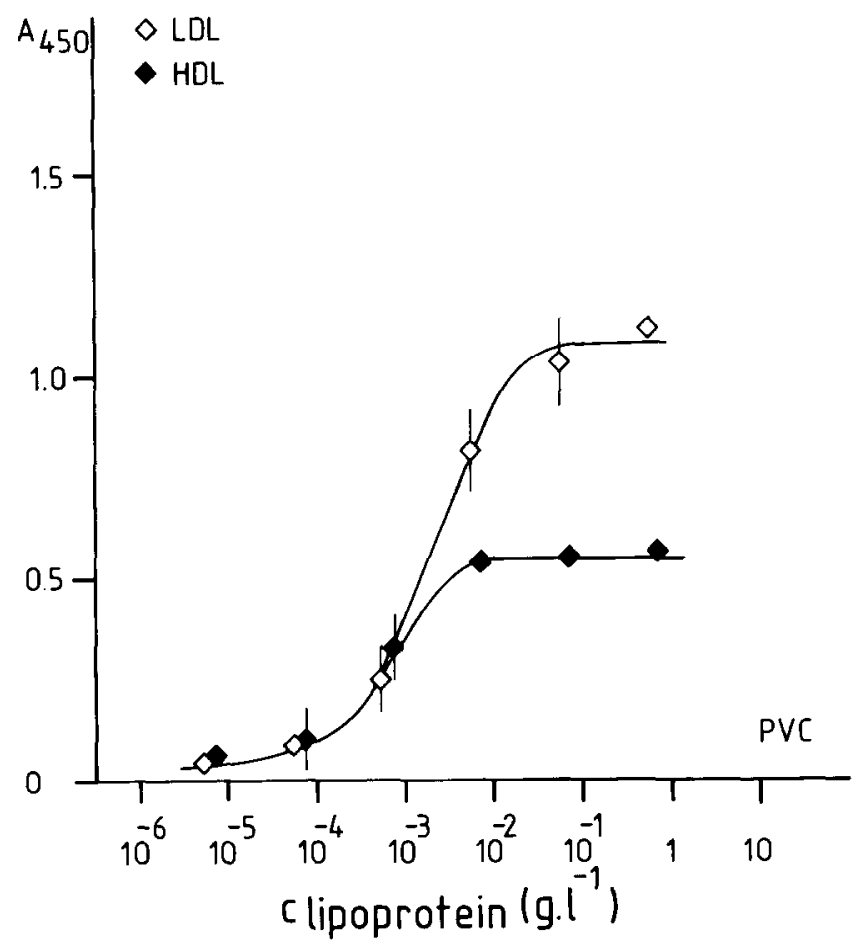

Figure 4 Adsorption isotherms for the adsorption of $H D L$ and $L D L$ on PVC obtained by serial dilution of single lipoprotein solutions.

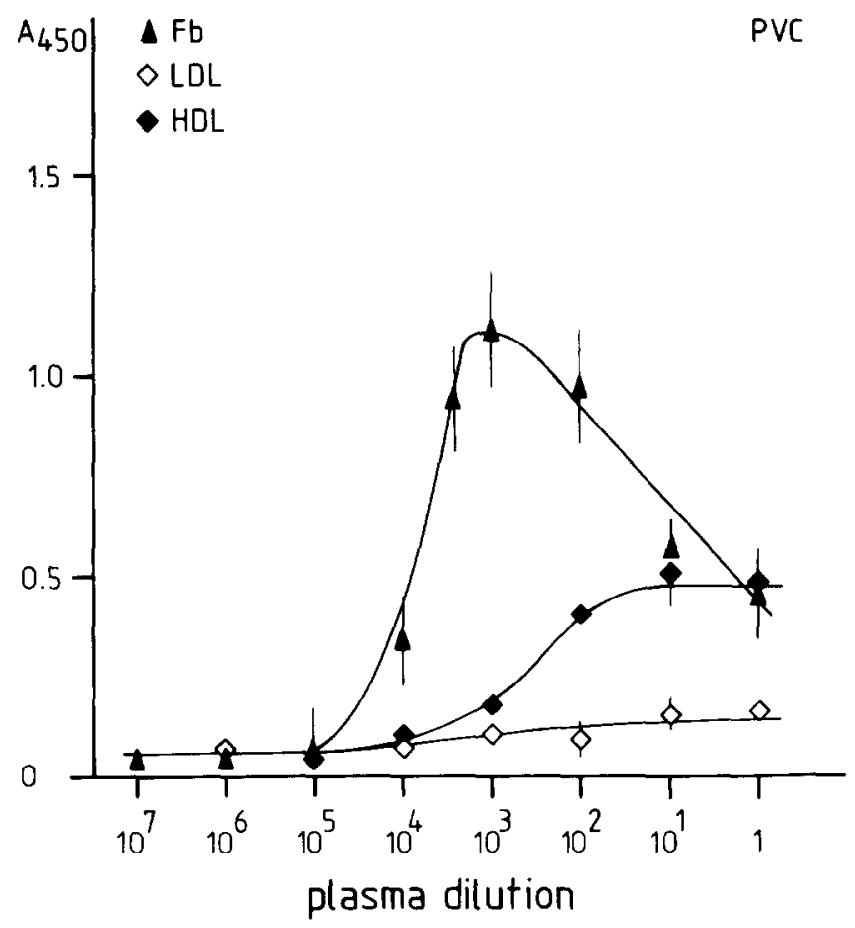

Figure 5 Adsorption isotherms for the adsorption of $F b, H D L$ and $L D L$ on PVC obtained by serial dilution of citrated plasma. 
different concentrations of HDL or LDL. PS surfaces precoated with LDL seem to be hardly altered with respect to the adsorption behaviour of Fb. Even when PS is precoated with a relatively concentrated solution of LDL (apo-B $\sim 1 \mathrm{~g} \cdot \mathrm{I}^{-1}$ ) the amount of $\mathrm{Fb}$ adsorbed from a solution of $\mathrm{Fb}$ is not very much reduced compared with the amount of $\mathrm{Fb}$ adsorbed onto a pure PS surface. When the PS surface is precoated with HDL a decrease of the $\mathrm{Fb}$ adsorption is observed, even if the HDL coating solution is very diluted.

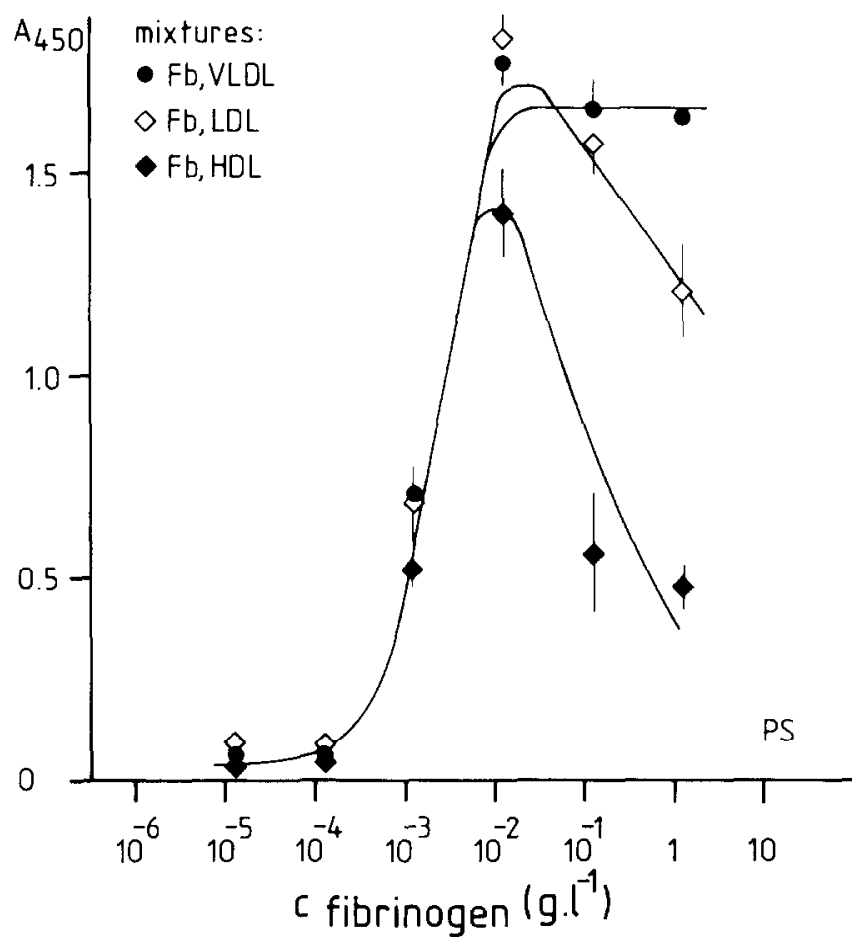

Figure 6 Adsorption isotherms for the adsorpton of Fb on PS in the presence of $V L D L, L D L$ and $H D L$, respectively.

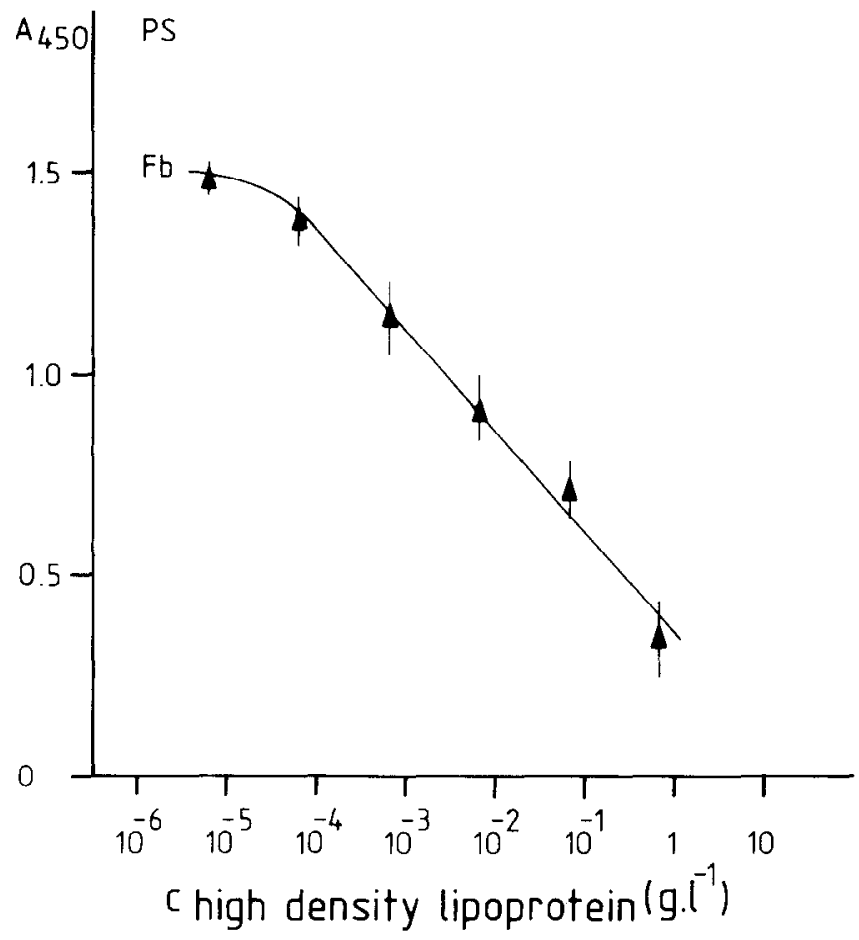

Figure 7 Adsorption of Fb on PS from mixtures with a fixed concentration of $\mathrm{Fb}\left(2.5 \mathrm{~g} \cdot \Gamma^{\mathrm{l}}\right)$ and increasing concentrations of $\mathrm{HDL}$.

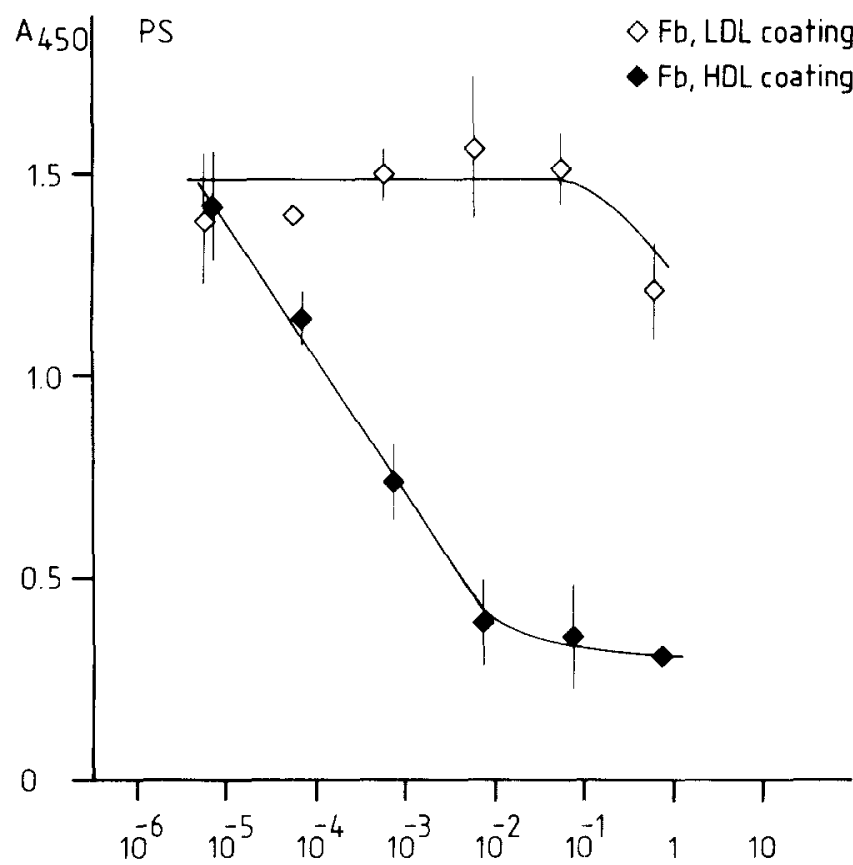

c lipoprotein in coating solution $\left(g . l^{-1}\right)$

Figure 8 Adsorption of $F b$ from a Fb solution $\left(2.5 \mathrm{~g} \cdot \Gamma^{-1}\right)$ on $P S$, precoated with $L D L$ and $H D L$, respectively.

The present experimental results strongly suggest that a preferential adsorption of HDL from plasma is the cause of severely reduced adsorption of blood proteins onto polymer surfaces compared with the adsorption of these proteins from protein solutions.

As reported in the literature ${ }^{11,12}$ the amount of HDL in the blood plasma of haemodialysis patients is decreased compared to normal subjects. It is conceivable that the contact of the circulating blood with large surface area of a dialyser membrane results in a relatively large adsorption of HDL Therefore, a frequent use of artificial kidneys may be responsible for the reduced $\mathrm{HDL}$ levels reported. As a low HDL level has been related to the occurrence of cardiovascular disease ${ }^{11}$ it would be of interest to investigate the effect of precoating biomaterials, such as used in extracorporeal blood treatment devices, with HDL in order to counteract the negative effects mentioned above.

\section{ACKNOWLEDGEMENT}

This work was supported by a grant from Organon Teknika. We are indebted to Dr H.J. Kempen (Gaubius Institute, Leiden, The Netherlands) for his assistance in isolating the lipoproteins.

\section{REFERENCES}

1 Feijen, J., Beugeling, T., Bantjes, A. and Smit-Sibinga, C, Th. Biomaterials and interfacial phenomena, in Advances in Cardiovascular Physics 3, (Ed. D.N. Ghista), Karger, Basel, 1979 , pp 100-132

2 Kochwa, S., Litwak, R.S, and Rosenfield, R.E., Blood elements at foreign surfaces: a biochemical approach to the study of the adsorption of plasma proteins, Ann. NY Acad. Sci. 1977, 283 37-49

3 Kim, S.W. Lee, R.G. Oster, H., Coleman, D., Andrade, J.D. Lentz. D.J. and OIsen, D., Platelet adhesion to polymer surfaces, Trans. Amer. Soc. Artif. Intern. Organs. 1974, 20, 449-455 
4 Brash, J.L., Uniyal, S. and Chan, B.M.C., Interactions of proteins in plasma with various foreign surfaces. Artificial Organs 1981, 5 (suppl). 475-477

5 Breemhaar, W., Ellens, D.J., Beugeling, T. and Bantjes, A., A novel application of a two step enzyme immuno assay for the investigation of the blood compatibility of materials, in Life Support Systems, Proceedings IX Annual Meeting ESAO, (Ed. J. Belenger). W.B. Saunders Company Ltd, Eastbourne (UK). 1982, pp 295-300

6 Redgrave, T.G., Roberts, D.C.K. and West, C.E., Separation of plasma lipoprotcins by density-gradient ultracentrifugation, Analytical Biochemistry 1975, 65, 42-49

7 Carlsson, J., Drevin, H. and Axén, R., Protein thiolation and reversible protein-protein conjugation. $N$-succinimıdyl 3-(2-pyridyldithio)propionate a new heterobifunctional reagent, Biochem. J. 1978, 173, 723-737

8 Bos, E.S., Doelen, A.A. van der, Rooij, M. van and Schuurs,
A.H.W.M., 3, 3', 5, 5' -tetramethylbenzidine as Ames test. Negative chromogen for horse radish peroxidase in enzyme immuno assay, J. Immunoassay 1981, 2, 187-192

9 Norde, W. and Lijklema, J., The adsorption of human plasma albuinin and bovine pancreas ribonuclease at negatively charged polystyrene surfaces. I. Adsorption isotherms. Effect of charge, ionic strength and temperature, J. Colloid Interface Sci. 1978, 66, 257-265

10 Kim, S.W. and Lee, R.G., Adsorption of blood proteins onto polymer surfaces, Adv. Chem. Ser. 1975, 145, 218-229

11 Bagdade, J.D. and Alberts, J.J., Plasma high-density lipoprotein concentrations in chronic-hemodialysis and renal-transplant patients, N. Engl. J. Med. 1977, 296, 1436-1439

12 Levire, J., Falk, B., Henriquez, M., Raja, R.M., Kramer, M.S. and Rosenbaum, J.L., High density lipoproteins - correlations with cardiovascular disease in hemodialysis patients, Trans. Amer. Soc. Artif. Intern. Organs. 1978, 24, 43-47 